\title{
Evaluation of Chemical Composition, Antibacterial, Antifungal, and Cytotoxic Activity of Laurus nobilis L Grown in Saudi Arabia
}

\author{
Humaira Rizwana* (D), Noorah Al Kubaisi (D), Nadeen N. Al-Meghailaith (D), \\ Nadine MS Moubayed (D) and Gadah Albasher ${ }^{1}$ (D)
}

Department of Botany and Microbiology, College of Science, King Saud University, P.O. Box 22452, Riyadh - 11495, Kingdom of Saudi Arabia. ${ }^{1}$ King Saud University, Department of Zoology, College of Science, Riyadh, Saudi Arabia.

\begin{abstract}
Present study aimed to evaluate the chemical composition, antibacterial, antifungal, and cytotoxic activity of Laurus nobilis grown in Tabuk region of Saudi Arabia. Dried leaves of $L$. nobilis were extracted with various solvent with increasing polarities. Solvent extracts exhibited variable inhibition zones against bacterial pathogens, however all the solvent extracts showed significant inhibition against fungal pathogens. Acetone extracts had the largest inhibition zone against Streptococcus pnemoniae $(37.16 \pm 0.23 \mathrm{~mm})$ while ethanol and methanol extract showed the most efficient percentage inhibition against mycelial growth of Alternaria alternata (91.33 $\pm 0.47 ; 90.66 \pm 0.94)$. High cytotoxicity was demonstrated by methanol and aqueous extracts (IC50 $14.90 \mu \mathrm{g} / \mathrm{ml}, 24.56 \mu \mathrm{g} / \mathrm{ml}$ ), while acetone extracts showed moderate effects on cell inhibition (IC50 $41.43 \mu \mathrm{g} / \mathrm{ml}$ ).The significant activity shown by the bay leaf extracts could be attributed to monoterpene hydrocarbons, oxygenated monoterpenes, phenylpropanoids, phenols, and other important phytoconstituents identified in GC- MS and FTIR studies. Our findings clearly show significant antifungal, antibacterial and cytotoxic activity of solvent extracts of bay leaves, which could be attributed to the presence of wide range of phytochemicals. Since plants derived natural products are less toxic, cheaper, and have negligible side effects, they would serve as an excellent alternative to antimicrobial and chemotherapeutic drugs.

Keywords: Laurus nobilis, solvent extracts, GCMS, cytotoxic, antibacterial, antifungal.
\end{abstract}

*Correspondence: hrizwana@ksu.edu.sa

(Received: 02 November 2019; accepted: 17 December 2019)

Citation: Humaira Rizwana, Noorah Al Kubaisi, Nadeen N. Al-Meghailaith, Nadine MS Moubayed and Gadah Albasher, Evaluation of Chemical Composition, Antibacterial, Antifungal, and Cytotoxic Activity of Laurus nobilis L Grown in Saudi Arabia, J Pure Appl Microbiol., 2019; 13(4):2073-2085. https://doi.org/10.22207/JPAM.13.4.19

(C) The Author(s) 2019. Open Access. This article is distributed under the terms of the Creative Commons Attribution 4.0 International License which permits unrestricted use, sharing, distribution, and reproduction in any medium, provided you give appropriate credit to the original author(s) and the source, provide a link to the Creative Commons license, and indicate if changes were made. 


\section{INTRODUCTION}

Medicinal plants are used worldwide to cure many diseases. Due to the undesirable side effects of modern synthetic pharmaceuticals and the simultaneous increase in microbes with multidrug resistance, traditional herbal approach to cure diseases is in vogue. Saudi Arabia represents one of the most biodiverse areas in the Arabian Peninsula ${ }^{1}$. Tabuk, is located in the Northwest region of Saudi Arabia and is well known for its diverse flora and fauna ${ }^{2}$. Herbal medicine (both native and non-native plants) is an ancient tradition in Saudi Arabia. Plants and their different parts possess a wide array of chemical components, which are used in ethano pharmacological research and have been explored since ages because of their immense benefits.

Laurus nobilis (family Lauraceae) is a small tree or shrub, native to the Mediterranean and European region. The leaves are called bay leaves or bay laurel and used as a spice and flavouring agent ${ }^{3}$, to treat flatulence, epigastric pain, gastrointestinal disorders ${ }^{4}$, epilepsy ${ }^{5}$, and have anti-inflammatory, analgesic ${ }^{6}$, antioxidant ${ }^{7}$, antibacterial ${ }^{8}$, antidiarrheal ${ }^{9}$, and antiproliferative ${ }^{10}$ properties.

Based on previous reports and literature collected, L. nobilis contains several important and potential secondary metabolites which could serve as excellent antimicrobial and anticancer agents. Hence, we explored the chemical composition, antibacterial, antifungal, and anticancer activity of Laurus nobilis leaves growing in Tabuk region of Saudi Arabia. To our knowledge, this is the first time leaves from Tabuk have been explored for their anticancer and antimicrobial activity.

\section{MATERIALS AND METHODS \\ Plant material}

The leaves of $L$. nobilis were collected from Tabuk region during the month of February (2018), and identified by Dr Najat Bukhari and Dr Mona Al Wahibi, Plant Taxonomist, Department of Botany. The leaves were thoroughly washed, dried, and grinded to fine powder, and used for the experiments throughout the research.

\section{Preparation of Extracts}

Preparation of extracts was done by following the method of Do et al. ${ }^{11}$, with minor modification. Various solvents (Water, ethanol, methanol, acetone, ethyl acetate, and chloroform) with increasing polarities were used for extraction purposes. Twenty grams of powdered leaves were added to $100 \mathrm{ml}$ of water, separately in conical flasks and shaken on a rotator shaker for $24 \mathrm{~h}$. Further, the crude extracts were filtered and dried using rotary evaporator, after which their extraction yields were calculated. The dried residues were reconstituted with respective mother solvents to obtain a fixed final volume of extracts.

\section{Microorganisms}

All the bacterial and fungal isolates used in the study were procured from King Khaled hospital, Riyadh, Saudi Arabia. The bacterial strains screened were Enterococcus faecalis (ATCC 29212), Staphylococcus aureus (ATCC 25923), Streptococcus pneumoniae (hospital isolate), and Proteus mirabilis (hospital isolate). Fungal strains screened were Fusarium solani, Fusarium oxysporum, Alternaria alternata, and Bipolaris sp. Nutrient agar was used to maintain all the stock cultures of bacteria, while PDA was used for fungi.

\section{Antibacterial Activity}

The antibacterial activity of the crude solvent extracts was performed by using well diffusion method ${ }^{12}$. Sterile nutrient broth $(10 \mathrm{ml})$ was inoculated with fresh bacterial cultures and incubated for $24 \mathrm{~h}$ at $37^{\circ} \mathrm{C}$. The cultured broth was adjusted to $10^{8} \mathrm{CFU} / \mathrm{ml}$ corresponding to a turbidity of $0.5 \mathrm{McFarland}$ standards. A fixed volume (10 $\mu$ l) of the quantified broth was evenly spread on Muller Hinton agar plates and allowed to dry. After drying, the agar was aseptically punched using cork borer $(6 \mathrm{~mm})$ to make wells. Each well was filled with $50 \mu \mathrm{l}$ of the crude solvent extract and incubated for $24 \mathrm{~h}$ at $37^{\circ} \mathrm{C}$. Positive control was antibiotic disc of Tetracycline $(30 \mu \mathrm{g})$, while the extracting solvents served as negative control.

\section{Antifungal Activity}

The effect of solvent extracts on mycelial growth of test fungi was determined using poisoned food method ${ }^{13}$. Sterile petri plate was loaded with extract $(1 \mathrm{ml})$ followed by addition of potato dextrose agar $(19 \mathrm{ml})$ and the mixture was gently swirled to allow thorough mixing. Plates with amended media were allowed to solidify, after which a mycelial plug was placed centrally in the amended plate. Mycelial plugs $(6 \mathrm{~mm})$ were removed from the periphery of culture plates with 
actively growing mycelia (10 days). Culture plates were then incubated at $25 \pm 2^{\circ} \mathrm{C}$. Measurements were taken when the control plate showed growth covering the entire plate. Control plate contained media without any treatment (without extract). The assay was performed in triplicates and their mean values were noted.

The following formula was used to calculate the percentage inhibition of mycelial growth.

$$
\mathrm{PI}=\left(\mathrm{C}_{\mathrm{o}}-\mathrm{T}_{\mathrm{e}}\right) / \mathrm{C}_{\mathrm{o}} \times 100
$$

where $\mathrm{PI}$ stands for percentage inhibition, $-\mathrm{T}_{e}$ is the treatment and $C_{0}$ denotes the mean growth rate of control

\section{Minimum Inhibitory Concentration (MIC)}

Broth dilution method was used to determine the Minimum Inhibitory Concentration of both fungi and bacteria, by following the standard method of CLSI with slight modification ${ }^{14,15}$. Muller Hinton broth (bacteria) and Potato dextrose broth (fungi) were used to prepare a double fold dilution of extracts in the range $0.125 \mathrm{mg} / \mathrm{ml}-32 \mathrm{mg} / \mathrm{ml}$. Equal amount of broth and extract were added to a sterile test tube containing $5 \times 10^{5} \mathrm{CFU} / \mathrm{ml}$ bacterial spore suspension and $2 \times 10^{6} \mathrm{CFU} / \mathrm{ml}$ of fungal spore suspension separately. The tubes were incubated at $37^{\circ} \mathrm{C}$ for $24 \mathrm{~h}$ (bacteria) and $25 \pm$ $2^{\circ} \mathrm{C}$ for $7-9$ days (fungi). The lowest concentration showing no visible growth was regarded as its MIC. The assay was performed in triplicates and their mean values were noted.

Minimum bactericidal concentration (MBC) and Minimum fungicidal concentration (MFC)

The Minimum bactericidal ( $M B C$ ) concentration and Minimum fungicidal concentration (MFC) tests were conducted as an adjunct to MIC assay ${ }^{16}$. The lowest concentration inhibiting the growth of test pathogens in tubes were transferred on the respective agar plates, Muller Hinton Agar for bacteria and Potato Dextrose agar for fungi. The subcultured plates were incubated at $37^{\circ} \mathrm{C}$ for $24 \mathrm{~h}$ (bacteria) and 25 $\pm 2^{\circ} \mathrm{C}$ for $7-9$ days (fungi). Concentrations that did not show any growth on respective agar medium were regarded as their MBC and MFC.

\section{MTT Assay and IC50 Values}

Cell viability was evaluated by MTT assay (3--[4, 5-dimethylthiazol-2-yl]-2,5 diphenyl tetrazolium bromide) as described by ZhiDong et al. ${ }^{17}$, with slight modification. To a 96 well plate, $100 \mu$ l of Hela cells was added at a concentration of $2 \times 10^{5}$ cell/well and allowed to settle for $24 \mathrm{~h}$. Cells were maintained in their respective medium. After $24 \mathrm{~h}$ incubation, various concentrations of solvent extracts were added to the wells and further incubated for $24 \mathrm{~h}$. After the incubation, $100 \mu \mathrm{l}(5 \mathrm{mg} / \mathrm{ml})$ of $0.22 \mu \mathrm{m}$ filter-sterilized 3-(4,5-dimethylthiazol-2yl)-2,5-diphenyltetrazolium bromide (MTT, Sigma Aldrich, UK) was added to the wells at $37^{\circ} \mathrm{C}$. Cells treated with MTT solution were incubated for 4 $\mathrm{h}$, and DMSO $(100 \mu \mathrm{l})$ was later added to solubilize formazan crystals. The plate was finally read using a 96 well plate reader (Molecular Devices -SPECTRA max- PLUS384) at $570 \mathrm{~nm}$. DMSO served as negative control and Doxorubicin was positive control.

\section{GC -MS Analysis}

Acetone extracts of $L$. nobilis were used for gas chromatography-mass spectrometry (GC) MSD) analysis, using Agilent technologies model 7890GC coupled with a mass detector Agilent 5975 GC/MSD. Agilent J\&W HP-5MS (phenyl methyl siloxane, $30 \mathrm{~m}^{\prime} 0.25 \mathrm{~mm}, 0.25 \mu \mathrm{m}$ ) analytic column was also used in the analysis, and helium ( $1 \mathrm{~mL}$ / $\mathrm{min}$ ) was used to separate components. Following are the standardised parameters adopted during the GC extraction: oven temperature of $45^{\circ} \mathrm{C}(2$ min) was increased to a temperature of $200^{\circ} \mathrm{C}$ at the rate of $3^{\circ} \mathrm{C} / \mathrm{min}$, solvent delay time was $5 \mathrm{~min}$, inlet line temperature was $200^{\circ} \mathrm{C}$, and ion source temperature was $230^{\circ} \mathrm{C}$. Mass spectra were taken at $70 \mathrm{eV}$, and acquisition mode-scan was $40-550$ am. Ninety minutes was the GC run time. The interpretation of mass spectrum and identification of phytocompounds present in the extracts were performed using the database of NIST libraries. FTIR

Nicolet 6700 spectrometer (Thermo Scientific, USA) equipped with DTGS detector and beam splitter was used in studying the IR spectrum of methanol and aqueous extracts. The IR spectrum obtained was analysed (OMNIC software) and scanned in the range of 4004000 $\mathrm{cm}-1$.

\section{Statistical Analysis}

All the tests in the present study were performed in triplicates and the data obtained are expressed as the mean \pm standard deviation (S.D.). Cytotoxicity graph was generated in excel 
as percentage cell viability using dose dependent curves. Graph pad prism (Version 7.00 for Windows GraphPad Software Inc.) was used in calculating the $\mathrm{IC}_{50}$ by generating standard curve with regression analysis.

\section{RESULTS}

\section{Extraction}

Solvents with increasing polarity were used for extraction purpose. Methanol extracts gave the highest yield (52\%) followed by ethanol $(49 \%)$, water $(27 \%)$, acetone (12\%), ethyl acetate (12\%) and chloroform (10\%).

\section{Antibacterial Activity}

Solvent extracts of $L$. nobilis examined in the present study exhibited significant antibacterial activity except the aqueous extracts (Table 1). Acetone extracts followed by ethyl acetate and methanol displayed significant inhibition against all the bacterial isolates tested. However, aqueous extracts were least inhibitory. Maximum zone of inhibition was observed with acetone extracts $(37.16 \pm 0.23)$ and ethyl acetate extracts (25.00 \pm 0.81 ) against $S$. pneumonia. Proteus mirabilis was also strongly inhibited by acetone extracts (24.00 \pm 0.81 )

\section{Antifungal Activity}

Bay leaf extracts demonstrated significant inhibition against radial mycelial growth of test fungi (Table 2). It was noticed that methanol and ethanol extract effectively inhibited mycelial growth of $A$. alternata, F. solani and F. oxysporum. Highest inhibitory activity was observed by ethanol and methanol extracts against $A$. alternata $(91.33$ $\pm 0.47 ; 90.66 \pm 0.94)$. Aqueous extracts exhibited least antifungal activity amongst all the extracts screened.

MIC, MBC and MFC of $L$. nobilis extract against test isolates

The results of MIC, MBC and MFC are shown in Table below (Table 3, 4). The MIC and $\mathrm{MBC}$ values for both bacteria and fungi ranged between 8 to $>32 \mathrm{mg} / \mathrm{ml}$. All the bacterial strains were inhibited by acetone extracts with an MIC of 0.125 - $2 \mathrm{mg} / \mathrm{ml}$. In general, aqueous extracts could not inhibited the growth of E. coli, P. mirabilis and S. pneumoniae at $32 \mathrm{mg} / \mathrm{ml}$ and were least inhibitory towards $S$. aureus and $E$. faecalis $(>32 \mathrm{mg} / \mathrm{ml})$. The MIC values for ethanol and methanol extracts against fungi ranged between $0.125-0.25 \mathrm{mg} / \mathrm{ml}$ while the MFC was $0.125-0.5$ $\mathrm{mg} / \mathrm{ml}$. Bipolaris $s p$ was inhibited by all the extracts in the range of $0.125-16 \mathrm{mg} / \mathrm{ml}$. Aqueous extracts could not inhibit F.solani and F.oxysporum at 32 $\mathrm{mg} / \mathrm{ml}$.

\section{Cytotoxic Activity of Extracts and IC}

All the crude extracts were tested for their in vitro anticancer activity against HeLa cell through MTT assay. Fig. 1 shows the cell viability of extracts (in a dose dependent manner). All the extracts inhibited HeLa cells, except ethyl acetate extracts. Cell viability data is presented on a graph, at the highest concentration of $100 \mu \mathrm{g} / \mathrm{ml}$. Aqueous extracts, acetone, and methanol extracts caused $86 \%, 58 \%$, and $76 \%$ inhibition respectively. The $\mathrm{IC}_{50}$ for methanol, aqueous, and acetone

Table 1. Inhibitory Activity of Laurus nobilis Solvent Extracts Against Pathogenic

\begin{tabular}{|c|c|c|c|c|c|c|c|}
\hline \multirow[t]{2}{*}{ Bacterial Strains } & \multicolumn{7}{|c|}{ Solvent Extract Examined -Zone of Inhibition ( $\mathrm{mm}$ ) } \\
\hline & Aqueous & Methanol & Ethanol & Acetone & Chloroform & Ethyl Acetate & Control \\
\hline Escherichia coli & $\mathrm{NI}$ & $\begin{array}{c}8.66 \pm \\
0.47\end{array}$ & $\begin{array}{l}9.00 \pm \\
0.00\end{array}$ & $\begin{array}{c}23.33 \pm \\
0.94\end{array}$ & $\begin{array}{c}24.00 \pm \\
0.81\end{array}$ & $\begin{array}{c}17.00 \pm \\
0.81\end{array}$ & $\begin{array}{c}35.66 \pm \\
0.62\end{array}$ \\
\hline $\begin{array}{l}\text { Proteus } \\
\text { mirabilis }\end{array}$ & $\begin{array}{c}12.16 \pm \\
0.23\end{array}$ & $\begin{array}{c}15.33 \pm \\
0.47\end{array}$ & $\begin{array}{c}18.33 \pm \\
1.24\end{array}$ & $\begin{array}{c}24.00 \pm \\
0.81\end{array}$ & $\mathrm{NI}$ & $\begin{array}{c}28.00 \pm \\
0.00\end{array}$ & $\mathrm{NI}$ \\
\hline $\begin{array}{l}\text { Staphylococcus } \\
\text { aureus }\end{array}$ & $\begin{array}{c}11.33 \pm \\
1.02\end{array}$ & $\begin{array}{c}12.66 \pm \\
0.47\end{array}$ & $\begin{array}{c}10.00 \pm \\
1.62\end{array}$ & $\begin{array}{c}16.66 \pm \\
0.94\end{array}$ & $\begin{array}{c}15.00 \pm \\
0.00\end{array}$ & $\begin{array}{c}8.33 \pm \\
0.94\end{array}$ & $\begin{array}{c}34.16 \pm \\
0.23\end{array}$ \\
\hline $\begin{array}{l}\text { Streptococcus } \\
\text { pnemoniae }\end{array}$ & $\mathrm{NI}$ & $\begin{array}{c}22.00 \pm \\
0.40\end{array}$ & $\begin{array}{c}17.33 \pm \\
0.47\end{array}$ & $\begin{array}{c}37.16 \pm \\
0.23\end{array}$ & $\begin{array}{c}19.00 \pm \\
0.40\end{array}$ & $\begin{array}{c}25.00 \pm \\
0.81\end{array}$ & $\mathrm{NI}$ \\
\hline $\begin{array}{l}\text { Enterococcus } \\
\text { faecalis }\end{array}$ & $\begin{array}{c}10.33 \pm \\
0.94\end{array}$ & $\begin{array}{c}18.66 \pm \\
0.62\end{array}$ & $\begin{array}{c}16.00 \pm \\
0.62\end{array}$ & $\begin{array}{c}24.00 \pm \\
0.00\end{array}$ & $\begin{array}{c}11.33 \pm \\
0.47\end{array}$ & $\begin{array}{c}21.66 \pm \\
1.24\end{array}$ & $\begin{array}{c}26.00 \pm \\
0.72\end{array}$ \\
\hline
\end{tabular}

All data are expressed as mean \pm standard deviation, where $\mathrm{n}=3$. Control Tetracycline. $\mathrm{NI}$ - not inhibited. 
Table 2. Inhibitory Activity of Laurus nobilis Solvent Extracts Against Fungal strains.

\begin{tabular}{lccccccc}
\hline Fungi Tested & \multicolumn{7}{c}{ Solvent extracts examined-Percentage Inhibition(\%) } \\
\cline { 2 - 7 } & Aqueous & Methanol & Ethanol & Acetone & Chloroform & Ethyl Acetate & Control \\
\hline Fusarium solani & $38.33 \pm$ & $81.00 \pm$ & $84.66 \pm$ & $62.33 \pm$ & $57.00 \pm 0.70$ & $50.66 \pm$ & $88.00 \pm$ \\
& 0.47 & 0.81 & 0.94 & 0.47 & & 0.62 & 0.70 \\
Fusarium & $36.00 \pm$ & $78.33 \pm$ & $80.00 \pm$ & $56.16 \pm$ & $70.66 \pm 0.94$ & $62.00 \pm$ & $86.33 \pm$ \\
oxysporum & 0.81 & 1.24 & 0.81 & 1.02 & & 1.00 & 0.47 \\
Alternaria & $50.16 \pm$ & $90.66 \pm$ & $91.33 \pm$ & $34.00 \pm$ & $45.00 \pm 1.08$ & $48.66 \pm$ & $90.00 \pm$ \\
alternata & 0.23 & 0.94 & 0.47 & 0.81 & & 0.94 & 0.81 \\
Bipolaris sp & $42.66 \pm$ & $77.33 \pm$ & $76.00 \pm$ & $55.66 \pm$ & $79.00 \pm 0.40$ & $60.00 \pm$ & $84.16 \pm$ \\
& 0.62 & 0.84 & 0.00 & 1.02 & & 1.62 & 1.02 \\
\hline
\end{tabular}

All data are expressed as mean \pm standard deviation where $n=3$. Control- Voriconazole

extracts was $14.90 \mu \mathrm{g} / \mathrm{ml}, 24.56 \mu \mathrm{g} / \mathrm{ml}$, and 41.43 $\mu \mathrm{g} / \mathrm{ml}$ respectively.

\section{GC-MS}

Crude acetone extract exhibited significant antimicrobial and cytotoxic activities, hence was subjected to GCMS analysis. Acetone extracts showed the presence of monoterpene hydrocarbons, oxygenated monoterpenes, phenylpropanoids, phenols and many others important compounds as shown in Table 5. Chemical composition of acetone extracts showed the presence of compounds such as Bicyclo (3.1.1) hept-2-ene,2,6,6-trimethyl, 6,6-Dimethyl-2-methylenebicyclo[3.1.1] heptane ( $\alpha$ and $\beta$ pinene), o-xylene, $p$-xylene, 3-carene, terpenyl acetate, $\gamma$ terpinene, eugenol, phenol, 2-methoxy-4(2propenyl)-acetate, Camphene, and 9-Hexadecen-1-ol,(Z), Phenol,2-methoxy-4(2-propenyl)-acetate,Cyclohexene.1-methyl-4-(1methylethylidene) and Terpineol acetate.

\section{FTIR}

FTIR of methanol and aqueous extract was performed, as these extracts demonstrated significant antifungal and cytotoxic activity. IR spectroscopy of methanol and aqueous extract show a broad peak at $3295 \mathrm{~cm}^{-1}$ and $3285 \mathrm{~cm}^{-1}$, these peaks denotes the presence of phenolic compounds such as eugenol and terpineols. The two peaks in methanol extract at $2946 \mathrm{~cm}^{-1}$ and $2834 \mathrm{~cm}^{-1}$ are due to $\mathrm{C}-\mathrm{H}$ asymmetric and symmetric stretching of proteins, lipids and carbohydrates, while the peaks at $2169 \mathrm{~cm}^{-1}$ and $2018 \mathrm{~cm}^{-1}$ are due to $\mathrm{C}=\mathrm{C}$ stretches of alkyne molecules, similar peaks were also observed in aqueous extracts at 2026 and $2217 \mathrm{~cm}^{-1}$. The peak at $1647 \mathrm{~cm}^{-1} \& 1634 \mathrm{~cm}^{-1}$ in methanol and aqueous are related to $\mathrm{C}=\mathrm{C}$ stretching of the terpenes such as pinene, cymene and terpinene. The small peaks between $1947 \mathrm{~cm}^{-1}-1990 \mathrm{~cm}^{-1}$ were from $\mathrm{C}=\mathrm{C}$

Table 3. Minimum Inhibitory and Minimum Bactericidal Concentration (MIC and MFC) of Laurus nobius extracts

Solvent extract examined $(\mathrm{mg} / \mathrm{ml})$

\begin{tabular}{lccccccccccccc}
\hline \multirow{2}{*}{$\begin{array}{l}\text { Bacteria } \\
\text { tested }\end{array}$} & \multicolumn{2}{c}{ Aqueous } & \multicolumn{2}{c}{ Methanol } & \multicolumn{2}{c}{ Ethanol } & & \multicolumn{2}{c}{ Acetone } & \multicolumn{2}{c}{ Chloroform } & \multicolumn{2}{c}{ Ethyl acetate } \\
\cline { 2 - 6 } & $\mathrm{MIC}$ & $\mathrm{MBC}$ & $\mathrm{MIC}$ & $\mathrm{MBC}$ & $\mathrm{MIC}$ & $\mathrm{MBC}$ & $\mathrm{MIC}$ & $\mathrm{MBC}$ & $\mathrm{MIC}$ & $\mathrm{MBC}$ & $\mathrm{MIC}$ & $\mathrm{MBC}$ \\
\hline E. coli & $\mathrm{NI}$ & $\mathrm{NI}$ & $\mathrm{NI}$ & $\mathrm{NI}$ & $>32$ & $\mathrm{NT}$ & 0.25 & 1 & 0.25 & 1 & 2 & 2 \\
P. mirabilis & $\mathrm{NI}$ & $\mathrm{NI}$ & 8 & 16 & 4 & 8 & 0.125 & 0.125 & $\mathrm{NI}$ & $\mathrm{NT}$ & 0.125 & 0.25 \\
S. aureus & $>32$ & $\mathrm{NT}$ & 32 & $\mathrm{NT}$ & $\mathrm{NI}$ & $\mathrm{NI}$ & 0.25 & 0.5 & 2 & 2 & $\mathrm{NI}$ & $\mathrm{NI}$ \\
S. pneumoniae & $\mathrm{NI}$ & $\mathrm{NI}$ & 0.125 & 0.5 & 2 & 8 & 0.125 & 0.125 & 0.5 & 0.5 & 1 & 2 \\
E. faecalis & $>32$ & $\mathrm{NI}$ & 0.125 & 0.25 & 0.25 & 0.25 & 0.125 & 0.125 & 16 & 32 & 0.125 & 0.25 \\
\hline
\end{tabular}

NI-Not Inhibited. E. coli- Escherichia coli, P. mirabilis- Proteus mirabilis, S. aureus- Staphylococcus aureus, S.pneumoniaeStreptococcus pnemoniae, E. faecalis - Enterococcus faecalis 
asymmetric stretches of alkenes (Table 6,7 \& Fig. 1,2).

\section{DISCUSSION}

Extraction is the first step by which chemical compounds are obtained from plant material. In order to maximise the extraction of biologically active compounds, various solvents were screened in this study. Extraction yields significantly varied with different solvents. Methanol followed by ethanol and water gave higher yields than others. Therefore, the extraction yields increased with increasing polarity of the solvents, indicating that both, the extracting efficiency and extractable bioactive compounds favoured solvents with high polarity. Our findings

Table 4. Minimum Inhibitory and Minimum Fungicidal Concentration (MIC and MFC) of Laurus nobius extracts

Solvent extract examined $(\mathrm{mg} / \mathrm{ml})$

\begin{tabular}{|c|c|c|c|c|c|c|c|c|c|c|c|c|}
\hline \multirow{2}{*}{$\begin{array}{l}\text { Fungi } \\
\text { tested }\end{array}$} & \multicolumn{2}{|c|}{ Aqueous } & \multicolumn{2}{|c|}{ Methanol } & \multicolumn{2}{|c|}{ Ethanol } & \multicolumn{2}{|c|}{ Acetone } & \multicolumn{2}{|c|}{ Chloroform } & \multicolumn{2}{|c|}{ Ethylacetate } \\
\hline & MIC & MFC & MIC & MFC & MIC & MFC & MIC & MFC & MIC & MFC & MIC & MFC \\
\hline F. solani & $>32$ & $\mathrm{NI}$ & 0.125 & 0.125 & 0.125 & 0.125 & 0.25 & 0.5 & 0.5 & 1 & 1 & 1 \\
\hline F. oxysporum & $\mathrm{NI}$ & $\mathrm{NI}$ & 0.125 & 0.25 & 0.125 & 0.125 & 4 & 8 & 0.5 & 1 & 0.5 & 2 \\
\hline A. alternata & 4 & 8 & 0.125 & 0.125 & 0.125 & 0.125 & $>32$ & $\mathrm{NI}$ & 8 & 16 & 8 & 8 \\
\hline Bipolaris sp. & 8 & 16 & 0.25 & 0.5 & 0.25 & 0.25 & 0.5 & 1 & 0.125 & 0.25 & 0.5 & 0.5 \\
\hline
\end{tabular}

NI-Not Inhibited, F. solani -Fusarium solani, F. oxysporum -Fusarium oxysporum, A. alternata -Alternaria alternata

Table 5. GC-MS Analysis of Laurus nobilis Acetone Extract

\begin{tabular}{|c|c|c|c|}
\hline Name of Compound & $\begin{array}{l}\text { Retention } \\
\text { time }\end{array}$ & $\begin{array}{l}\text { Molecular } \\
\text { formula }\end{array}$ & $\begin{array}{c}\text { Peak area } \\
(\%)\end{array}$ \\
\hline 2,4-dichlorophenoxyacetic acid, methyl ester & 5.061 & $\mathrm{C}_{11} \mathrm{H}_{12} \mathrm{Cl}_{2} \mathrm{O}_{3}$ & 1.293 \\
\hline 2(Methoxycarbonyl)benzoic acid & 5.234 & $\mathrm{C}_{9} \mathrm{H}_{8} \mathrm{O}_{4}{ }^{12}$ & 1.004 \\
\hline Bicyclo (3.1.1) hept-2-ene,2,6,6-trimethyl & 6.359 & $\mathrm{C}_{20} \mathrm{H}_{32}^{8}$ & 11.914 \\
\hline Camphene & 7.149 & $\mathrm{C}_{10}^{20} \mathrm{H}_{16}^{32}$ & 0.434 \\
\hline o-Xylene & 7.606 & $\mathrm{C}_{8} \mathrm{H}_{10}$ & 1.025 \\
\hline p-Xylene & 8.564 & $\mathrm{C}_{8}^{8} \mathrm{H}_{10}^{10}$ & 0.931 \\
\hline$\gamma$-Terpinene & 31.485 & $\mathrm{C}_{10}^{8} \mathrm{H}_{16}$ & 1.422 \\
\hline Terpinyl acetate & 44.638 & $\mathrm{C}_{12} \mathrm{H}_{20} \mathrm{O}_{2}$ & 13.209 \\
\hline 3 Carene & 48.502 & $\mathrm{C}_{10} \mathrm{H}_{16}$ & 1.020 \\
\hline 6,6-Dimethyl-2-methylenebicyclo[3.1.1] heptane- & 54.372 & $\mathrm{C}_{10}^{10} \mathrm{H}_{16}^{16}$ & 2.380 \\
\hline Eugenol & 56.045 & $\mathrm{C}_{10} \mathrm{H}_{12} \mathrm{O}_{2}$ & 2.031 \\
\hline Phenol,2-methoxy-4-(2-propenyl)-acetate & 59.421 & $\mathrm{C}_{12}^{10} \mathrm{H}_{14}^{12} \mathrm{O}_{3}^{2}$ & 0.610 \\
\hline Cyclohexene.1-methyl-4-(1-methylethylidene) & 74.390 & $\mathrm{C}_{10} \mathrm{H}_{16}$ & 3.010 \\
\hline Terpineol, acetate & 75.641 & $\mathrm{C}_{12} \mathrm{H}_{20} \mathrm{O}_{2}$ & 5.511 \\
\hline 1,8-cineole & 76.523 & $\mathrm{C}_{10}^{12} \mathrm{H}_{18}^{20} \mathrm{O}^{2}$ & 6.313 \\
\hline $\begin{array}{l}\text { 1,2,3,4,5,6-Hexahydro-1,1,5,5-tetramethyl-2,4a- } \\
\text { methanonapthathalen-7(4aH)-one }\end{array}$ & 77.307 & $\mathrm{C}_{15} \mathrm{H}_{22} \mathrm{O}$ & 35.739 \\
\hline $\begin{array}{l}\text { 4a,7-Methano-4aH-naphth[1,8a-b]oxirene, } \\
\text { octahydro - 4,4,8,8-tetramethyl }\end{array}$ & 80.223 & $\mathrm{C}_{15} \mathrm{H}_{24} \mathrm{O}$ & 3.638 \\
\hline $\begin{array}{l}\text { 2,5-Cyclohexadiene-1,4-dione,2,6-bis } \\
\text { (1,1-dimethylethyl)- }\end{array}$ & 81.447 & $\mathrm{C}_{14} \mathrm{H}_{20} \mathrm{O}_{2}$ & 2.474 \\
\hline 9-Hexadecen-1-ol, (Z)- & 82.181 & $\mathrm{C}_{16} \mathrm{H}_{32} \mathrm{O}$ & 0.986 \\
\hline Oleyl alcohol & 84.413 & $\mathrm{C}_{18} \mathrm{H}_{36}^{32} \mathrm{O}$ & 0.610 \\
\hline Cyclopentadecanol & 86.107 & $\mathrm{C}_{15}^{18} \mathrm{H}_{30} \mathrm{O}$ & 1.221 \\
\hline Ricinoleic acid & 87.324 & $\mathrm{C}_{18}^{15} \mathrm{H}_{34} \mathrm{O}_{3}$ & 0.20 \\
\hline
\end{tabular}


are in agreement with previous reports which show that the extraction yields increased with increasing polarity of solvents ${ }^{18,19}$. It is known that plants possess a wide variety of bioactive compounds, which exhibit different solubility properties with different solvents, hence screening with different solvent helps identify the most appropriate solvent for biological studies ${ }^{19,20}$.

In the present study, bacterial isolates showed varied inhibitory activities against $L$. nobilis extracts, some isolates were significantly inhibited, while others responded poorly. In general, the Gram positive bacteria were inhibited with significant inhibition zones and exhibited low MIC values when compared to Gram negative bacteria. The two gram positive bacteria S. pneumoniae and E. faecalis showed least MIC values of $0.125 \mathrm{mg} /$ $\mathrm{ml}$ while $E$. coli was not inhibited at the highest test concentration of $32 \mathrm{mg} / \mathrm{ml}$. Similar to our findings, Malti and Amarouch, 2009 and Ramos et al., (2012), reported that ethanolic extracts of L. nobilis extracts were potent in inhibiting the Gram positive bacteria than the Gram negative isolates $^{21,22}$.

The variation in the inhibition zones and MIC values shown by Gram positive and negative bacteria is attributed primarily to the chemical composition and morphology of the bacterial cell membrane. The pronounced antibacterial activity shown by Gram positive bacteria could be due to the peptidoglycan layer which is permeable to the hydrophobic compounds present in the extract ${ }^{23}$. The resistance shown by Gram negative bacteria could be due to the lipopolysaccharide layer present in the cell membrane. The outer membrane of Gram negative bacteria is made

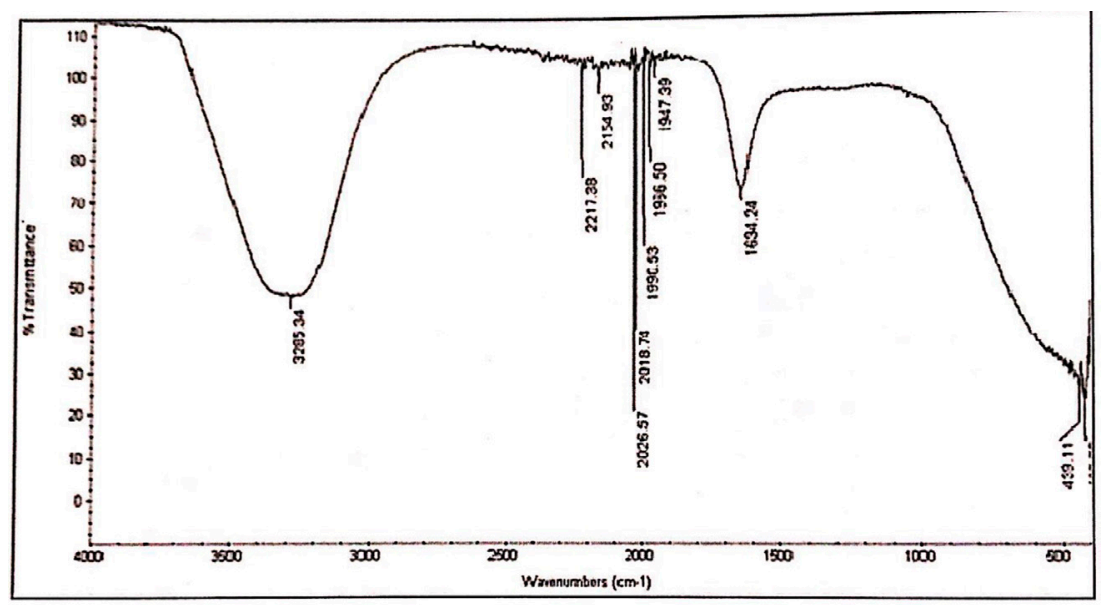

Fig. 1. IR spectrum of aqueous extracts of $L$. nobilis leaves

Table 6. FTIR spectrum of the aqueous extracts of L. nobilis leaves

\begin{tabular}{|c|c|c|c|}
\hline $\begin{array}{l}\text { Peak values } \\
\text { (frequency, } \mathrm{cm}^{-1} \text { ) }\end{array}$ & $\begin{array}{l}\text { Functional } \\
\text { group }\end{array}$ & $\begin{array}{l}\text { Peak values } \\
\text { (frequency, } \mathrm{cm}^{-1} \text { ) }\end{array}$ & $\begin{array}{l}\text { Functional } \\
\text { group }\end{array}$ \\
\hline \multirow[t]{2}{*}{3285} & Hydrogen bond & 3295 & Broad peak of $\mathrm{OH}$ stretch \\
\hline & $\mathrm{OH}$ stretches & 2946,2834 & Two peaks due to $\mathrm{CH}_{2}$ \\
\hline 2217 & $\mathrm{C} \equiv \mathrm{C}$ stretching & & asymmetry stretching \\
\hline 2154 & $\mathrm{C} \equiv \mathrm{C}$ stretching & & and symmetry stretching \\
\hline 2026 & $\mathrm{C}=\mathrm{C}$ stretch & 2169 & $\mathrm{C} \equiv \mathrm{C}$ stretch \\
\hline 2018 & $\mathrm{C}=\mathrm{C}$ stretch & 2018 & $\mathrm{C} \equiv \mathrm{C}$ stretch \\
\hline 1990 & $\mathrm{C}=\mathrm{C}$ bending & 1647 & $\mathrm{C} \equiv \mathrm{C}$ stretch \\
\hline 1966 & $\mathrm{C} \equiv \mathrm{C}$ stretch & 1449 & $\mathrm{CH}_{2}$ streches \\
\hline 1947 & $\mathrm{C} \equiv \mathrm{C}$ stretch & 1111 & $\mathrm{C}-\mathrm{O}$ stretches \\
\hline 1634 & $C=C$ Vibrations & 1015 & C-O stretches \\
\hline
\end{tabular}

Table 7. FTIR spectrum of the methanol extracts of L. nobilis leaves. 
up of tough and rigid lipopolysaccharide bilayer, with porins and uptake channels embedded in them, this kind of an arrangement is very efficient in resisting the entry of antimicrobial compounds ${ }^{24,25}$. According to Zgurskaya et al., the lipopolysaccharide layer is rigid and impermeable to hydrophobic compounds. The porins restrict the entry of hydrophilic compounds while the multidrug transporter pumps help in extruding the bioactive compounds. Hence, together they serve as an excellent permeability barrier to antimicrobial compounds across the cell membrane ${ }^{26}$.

All the fungal isolates screened interestingly exhibited strong inhibition by methanol extracts. Alternaria alternata showed maximum inhibition with methanol extracts, its inhibition was quite close to the antifungal voriconazole, indicating the potency of the extracts. However, there are very few reports that show the inhibition of emerging fungal pathogens by $L$. nobilis solvent extracts., especially the pathogens used in the present study (A. alternata, F. solani, F. oxysporum and C. gleosporoides).

The potent antimicrobial activity shown by acetone, methanol and ethanol extracts in a variable manner against a wide array of microorganisms in this study could be attributed to the richness of phenolic compounds along with monoterpenes hydrocarbons and oxygenated monoterpenes. Based on the antimicrobial activity we can deduce that methanol and acetone were efficient in extracting phenols and terpenes, which was further authenticated by GCMS and FTIR findings shown in Table 5,6,7. According to Bakari et al., phenolic compounds are more soluble in polar organic solvents than in non-polar solvents. They reported acetone as an efficient solvent to extract total phenols and flavonoid compounds ${ }^{19}$. Similarly, methanol and ethanol were reported as better solvents in extracting various phenolic compounds ${ }^{27}$. Recently promising antibacterial activity of $L$. nobilis extracts was reported by Fernandes et al., and they attributed it to the presence of phenolic compounds, like flavonoids ${ }^{28}$. Therefore, variable inhibition of test isolates is due to their sensitivity towards the bioactive compounds present in the solvent extracts which is influenced by the polarity of the extracting solvent.

Phenolic compounds have the ability to interfere and inhibit the synthesis of peptidoglycan ${ }^{29}$, modify the hydrophobicity of the membrane ${ }^{30}$ and cause damage to the membrane structures $^{31}$. Though the exact mechanism and mode of action of phytochemicals on microbes is not fully understood. However, studies indicate that phytochemicals like terpenes and terpenoids are known to alter membrane integrity by causing expansion of the cytoplasmic membrane, changing the fatty acid composition, and hyperpolarization due to lowering of $\mathrm{pH}$ internally, thereby destabilizing the membrane leading to cell membrane disruption ${ }^{32,33}$. Furthermore, the interaction of phytocompounds causes inhibition

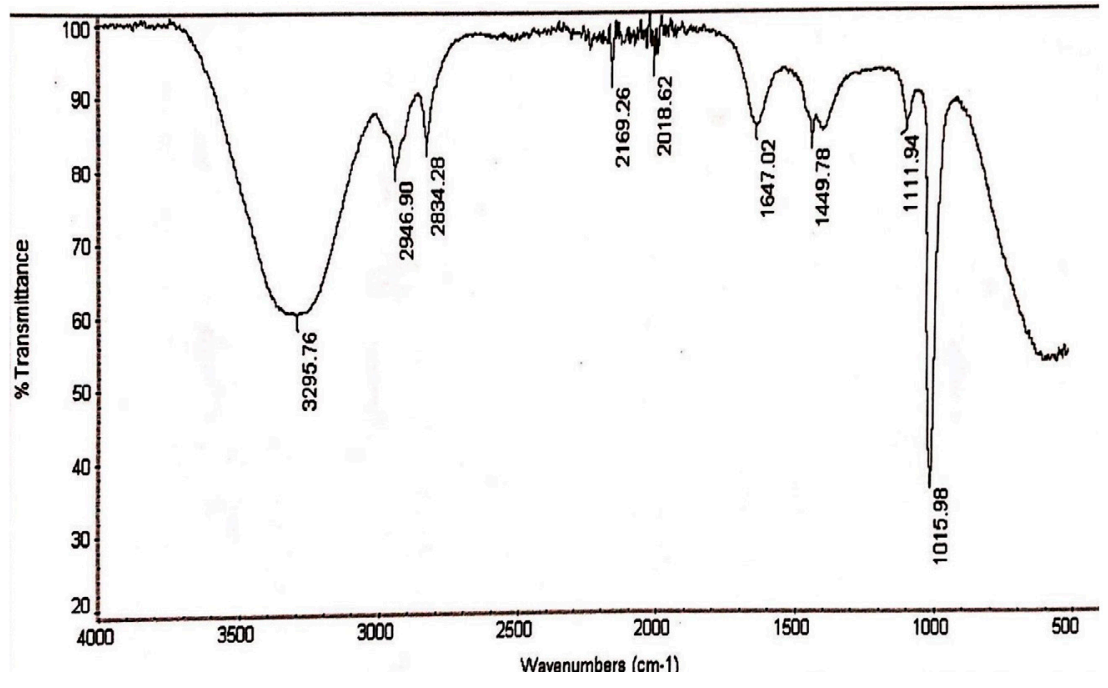

Fig. 2. IR spectrum of methanol extracts of L.nobilis leaves 
of respiration and alters the permeability of cell membranes $^{31}$.

GCMS analysis of acetone extracts shows presence of compounds like $\alpha$ pinene and $\beta$-pinene, 3 carene, terpinene, Terpinyl acetate 1,8-cineole,1,2,3,4,5,6-Hexahydro-1,1,5,5tetramethyl-2,4a-methanonapthathalen-7(4aH)one and eugenol besides others. Interestingly, previous reports show the presence of all the above-mentioned compounds in various solvent extracts of $L$. nobilis and exhibited antimicrobial activity ${ }^{28}$. Recently Vardapetyan et al., examined bay leaves from two different origins of South Caucasus (Armenia and Georgia). The ethanol extracts of the leaves from both regions showed the presence of o-Cymene, $\lambda$-pinene, and $D$-Limonene. However, the major component was 1,8-cineole, and minor quantities of acyclic and cyclic monoterpene phellandrene, $\gamma$ terpinene, and camphene were present ${ }^{34}$. Similarly, 1,8-cineole, terpinyl acetate, linalool, R-pinene, and sabiene were identified as the major compounds in bay leaves growing in Spain and Italy ${ }^{35,36}$. These findings are in accordance with our results as most of the above listed chemical constituents were present in the extracts evaluated in our study, denoting the richness of the extracts of plants grown in Saudi Arabia.

Some studies have reported the presence of certain sesquiterpenes and guaianolides such as phellandrene, $\beta$-eudesmol, $\alpha$-tocopherol, $\beta$-sitosterol and dehydrocostus lactone, which are missing in our findings ${ }^{37,38}$. Recent studies have shown the influence of environmental factors on the presence/ absence of important bioactive components and secondary metabolites in plant extracts and oils. Among the various factors that are responsible for varied chemical composition are temperature, altitude, sunlight, soil conditions, and water ${ }^{39,40}$. There are reports which show that the concentrations of certain terpenes and phenols in bay leaves vary with different drying methods ${ }^{36}$.

Most of the compounds like xylene, pinene, eugenol and terpeneine have shown antibacterial, and antifungal activity in previous reports. Monoterpenes hydrocarbons and oxygenated monoterpenes like $\alpha$ pinene and $\beta$-pinene, 3 carene, terpinene and Terpinyl acetate possess excellent antimicrobial ${ }^{41,42}$ and anticancer properties $^{43}$. Pinenes ( $\alpha$ pinene and $\beta$-pinene) have shown antibacterial ${ }^{43,44}$ antifungal ${ }^{45}$, antiviral 46 and insecticidal properties ${ }^{47}$. Similarly, eugenol has shown to exhibit antifungal ${ }^{48}$, antibacterial49, antibiofilm ${ }^{48,49}$, insecticidal ${ }^{50}$, anti-inflammatory ${ }^{51}$, and anticancer properties ${ }^{52}$. GCMS analysis of acetone extracts of $L$. nobilis in the present study revealed the presence of all the aforementioned compounds.

Significant cytotoxic activity recorded in this study could be attributed to the richness of phenolic compounds and terpenes present in

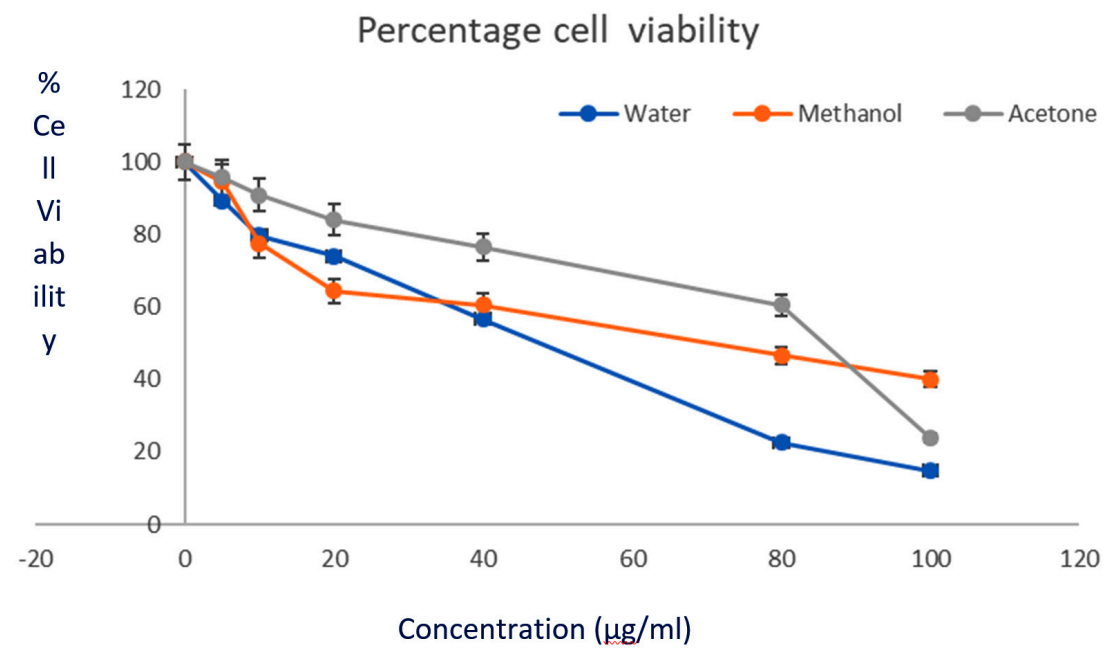

Fig. 3. Cytotoxic activity of $L$. nobilis extracts against HeLa cell line (MTT assay). The graph shows the \% cell viability. All data are expressed as mean \pm standard deviation $(n=3)$ 
methanol, ethanol and water extracts. As stated above, these solvents are excellent in extracting various phenols, flavonoids, terpenes, terpenoids and alkaloids, all of which are known for their antimicrobial, anti-inflammatory, antimutagenic and anticancer activities ${ }^{53}$. In fact, the presence of diverse terpenes and phenolic compounds present in the extracts actually prompted us to investigate their cytotoxic activities.

Plant derived compounds have different modes of action; however, most of them induce apoptosis without cytotoxic effect on normal cells ${ }^{54}$ . Recently it was reported that in phenols, the number of substitutes in the $\mathrm{OH}$-ring, increases its anti-proliferative and cytotoxic activities ${ }^{55}$. Similarly, terpenes, terpenoids, alkaloids and flavonoids induce cytotoxicity of breast cancer cells by activating the intrinsic pathway resulting in apoptosis ${ }^{55}$. Significant cytotoxic and antitumor activity of methanol and aqueous extracts of $L$. nobilis leaves towards a number of cancer cell lines, like $\mathrm{NCl}-\mathrm{H} 460$-lung cancer cells, cervical carcinoma, HCT15-colon carcinoma, breast adenocarcinoma and HepG2 -hepatocellular carcinoma have been reported earlier. High amounts of phenols and flavanols were responsible for the activity ${ }^{56}$. Similary, Berrington and Lall, reported acetone extracts of $L$. nobilis to inhibit HeLa cells strongly with an $\mathrm{IC}_{50}$ values of $34.46 \pm 0.48 \mu \mathrm{g} / \mathrm{mL}^{57}$. Our results are in agreement with the all the abovementioned findings as phenolic compounds, flavanones and terpenes were present in the extracts screened and could have contributed to the promising cytotoxic activity.

\section{CONCLUSION}

Our findings clearly show the presence of diverse phytochemicals in bay leaves grown in Saudi Arabia. The significant antimicrobial and cytotoxicity could be attributed to phenolic compounds along with Terpenes. Since drugs derived from plants are less toxic, cheaper, and with negligible side effects, they would serve as an excellent alternative to antimicrobial and chemotherapeutic drugs. Recently, several herbal extracts have been approved by FDA for clinical trials. An IC ${ }_{50}$ that is lower than $30 \mu \mathrm{g} / \mathrm{ml}$ is considered a very strong cytotoxic agent (American National Cancer Institute). The $I C_{50}$ of some extracts in our study was lower than this limit.
Keeping in mind their significant antibacterial, antifungal, and anticancer activities, they can serve as potential candidate for pharmaceutical industry.

\section{ACKNOWLEDGEMENTS}

This research project was supported by a Deanship of Scientific Research, King Saud University, Saudi Arabia. The authors would like to extend their sincere appreciation for funding this work.

\section{CONFLICTS OF INTEREST}

The authors declare that there is no conflict of interest.

\section{FUNDING}

None.

\section{AUTHORS' CONTRIBUTION}

HR designed the experimental work. NNA and NMSM carried out the experimental work. HR, NNA and NA analyzed the GCMS and IR analysis. GA assisted in analyzing the Cytotoxicity results. HR wrote the manuscript. NA reviewed and edited the manuscript.

\section{DATA AVAILABILITY}

The data that support the findings of this study are available with the corresponding author

\section{ETHICS STATEMENT}

No animal or human subjects were involved in the work related to this manuscript.

\section{REFERENCES}

1. Collenette S. In: Checklist of botanical species in Saudi Arabia. West Sussex (UK), International Asclepiad Society., 1998: pp.78.

2. Al-Mutairi K., Al-Shami S.A., Khorshid Z., Moawed M.M. Floristic diversity of Tabuk province, North Saudi Arabia. J. Anim. Plant. Sci., 2016; 26: 1019-1025.

3. Peris I., Blazquez M.A. Comparative GC-MS Analysis of Bay Leaf (Laurus nobilis L.) Essential Oils in Commercial Samples. Int. J. of Food Prop., 2015; 18: 757-762. https://doi.org/10.1080/10942912.2014.906451

4. Speroni E., Cervellati R., Dall Acqua S., Guerra M.C., Greco E., Govoni P. et al., Gastroprotective Effect and Antioxidant Properties of Different Laurus nobilis L. Leaf Extracts. J. Med. Food., 2011; 14: 499-504. https:// doi.org/10.1089/jmf.2010.0084

5. Aqili Khorasani M.S. Collection of drugs (Material Media) In: Enqelab-e-Eslami Publishing and Educational Organization, Teheran, Iran. 1992: pp. 624-630. 
6. Sayyah M., Saroukhani G., Peirovi A., Kamalinejad M. Analgesic and anti-inflammatory activity of the leaf essential oil of Laurus nobilis Linn. Phytother. Res., 2003; 17: 733-736. https://doi.org/10.1002/ptr.1197

7. Dall Acqua S., Cervellati R., Speroni E., Costa S., Guerra M.C., Stella L. et al., Phytochemical Composition and Antioxidant Activity of Laurus nobilis L. Leaf Infusion. J. Med. Food., 2009; 12: 869-876. https:// doi.org/10.1089/jmf.2008.0119

8. Chaudhry N.M.A., Tariq P. Bactericidal activity of black pepper, bay leaf, aniseed, and coriander against oral isolates. Pak. J. Pharma. Sci., 2006; 19: 214-218.

9. Qnais E.Y., Abdulla F.A., Kaddumi E.G., Abdalla S.S Antidiarrheal activity of Laurus nobilis $L$. leaf extract in rats. J. Med. Food., 2012; 15: 51-57. https://doi. org/10.1089/jmf.2011.1707

10. Abu-Dahab R., Kasabri V., Afifi F.U. Evaluation of the volatile oil composition and antiproliferative activity of Laurus nobilis L. (Lauraceae) on breast cancer cell line models. Rec. Nat. Prod., 2014; 8: 136-147.

11. Do Q. D., A.E. Angkawijaya., P.L., Tran-Nguyen et al., "Effect of extraction solvent on total phenol content, total flavonoid content, and antioxidant activity of Limnophila aromatica, J. Food. Drug. Anal.,2014; 22: 296-302. https://doi.org/10.1016/j.jfda.2013.11.001

12. NCCLS. Methods for dilution: antimicrobial susceptibility test for bacteria that grow aerobically M-7-A5. 5th ed. Vol. 20. Wayne PA: NCCLS; National Committee for Clinical Laboratory Standards 2000, pp. 2.

13. Dhiman R., Aggarwal N., Aneja K.R., Kaur M. In vitro antimicrobial activity of spices and medicinal herbs against selected microbes associated with juices. Int J. Microbiol., 2016; 10: 170-180.

14. Clinical and Laboratory Standards Institute (CLSI). Performance standards for antimicrobial susceptibility testing. 26th ed. Wayne: CLSI; 2016.

15. Clinical and Laboratory Standards Institute (CLSI). Reference Method for Broth Dilution Antifungal Susceptibility Testing of Filamentous Fungi.3rd Edition. document M38-A2. Wayne: Clinical and Laboratory Standards Institute; 2017

16. Tavichakorntrakool R., Lulitanond A., Sangka A., Sungkeeree S., Weerapreeyakul N. Antibacterial activity and bioactive compounds of $50 \%$ hydroethanolic extract of Alpinia zerumbet (Pers.) B.L. Burtt \& R.M. Sm. Asian. Pac. J. Trop. Biomed., 2019; 9: 204-208. https://doi.org/10.4103/2221-1691.259000

17. Zhi-Dong L.V., Liu X.P., Zhao W.J., Dong Q., Li F.N. Wang H.B. et al., Curcumin Induces Apoptosis in Breast Cancer Cells and Inhibits Tumour Growth In vitro and In Vivo. Int. J. Clin. Exp. Pathol., 2014; 7: 2818-2824.

18. Truong D.H., Nguyen D.H., Anh Ta N.T., Bui A.V., Do T.H., Nguyen H.C. Evaluation of the Use of Different Solvents for Phytochemical Constituents, Antioxidants, and In Vitro Anti-Inflammatory Activities of Severinia buxifolia. J. Food. Qual., 2019; Article ID 8178294, 9 pages. https://doi.org/10.1155/2019/8178294

19. Bakari S., Daoud A., Felhi S., Smaoui S., Gharsallah N., Kadri A. Proximate analysis, mineral composition, phytochemical contents, antioxidant and antimicrobial activities and GC-MS investigation of various solvent extracts of cactus cladode. Food. Sci. Technol., 2017; 37: 286-293. https://doi.org/10.1590/1678457x.20116

20. Abarca-Vargas R., Malacara C.F.P., Petricevich V.L. Characterization of Chemical Compounds with Antioxidant and Cytotoxic Activities in Bougainvillea $x$ buttiana Holttum and Standl, (var. Rose) Extracts. Antioxidants, 2016; 5: 45. https://doi.org/10.3390/ antiox 5040045

21. C. Ramos B., Teixeira I., Batista O., Matos, C., Serrano N.R., Neng J.M.F., Nunes N.M.L., Marques A. Antioxidant and antibacterial activity of essential oil and extracts of bay laurel Laurus nobilis Linnaeus (Lauraceae) from Portugal, Nat. Prod. Res., 2012., 26: 518-529. https://doi.org/10.1080/14786419.2010.53 1478

22. Malti J.E. and Amarouch H. Antibacterial effect, histological impact and Oxidative stress studies from Laurus nobilis extract. J. Food Qual.,2009., 32: 190-208. https://doi.org/10.1111/j.1745-4557.2009.00245.x

23. Ramesh kumar K. B., George V., Shiburaj S. Chemical composition and antibacterial activity of the leaf oil of Cinnamomum chemungianum Mohan \& Henry, 2007; 19(1): 98-100. https://doi.org/10.1080/10412905.20 07.9699238

24. Delcour A.H. Outer membrane permeability and antibiotic resistance. Biochim Biophys Acta, Proteins Proteomics, 2009; 1794: 808-816. https://doi. org/10.1016/j.bbapap.2008.11.005

25. Nikaido H. Molecular basis of bacterial outer membrane permeability revisited. Microbiol Mol Biol Rev: MMBR, 2003; 67: 593-656. [PubMed: 14665678]. https://doi.org/10.1128/MMBR.67.4.593-656.2003

26. Zgurskaya H.I., Lopez C.A., Gnanakaran S. Permeability Barrier of Gram-Negative Cell Envelopes and Approaches To Bypass It. ACS Infect. Dis., 2015 ; 1: 512522. https://doi.org/10.1021/acsinfecdis.5b00097

27. Siddhuraju P., and Becker, K. Antioxidant Properties of Various Solvent Extracts of Total Phenolic Constituents from Three Different Agroclimatic Origins of Drumstick Tree (Moringa oleifera Lam.) Leaves. J. Agri. Food. Chem., 2003; 51: 2144-2155. https://doi.org/10.1021/ jf020444+

28. Fernandez N.J., Natalia Damiani, Enrique Arturo Podaza, Josefa Fabiana Martucci,Diana Fasce, Federico Quiroz, Pablo Ezequiel Meretta, Silvina Quintana, Martin Javier Eguaras,Liesel Brenda Gende. Laurus nobilis L. Extracts against Paenibacillus larvae: Antimicrobial activity, antioxidant capacity, hygienic behavior and colony strength. Saudi Journal of Biological Sciences, 2019; 26: 906-912. https://doi. org/10.1016/j.sjbs.2018.04.008

29. Ogunlana E.O., Hoeglund S., Onawunmi G., Skoeld, O. Effects of lemongrass oil on the morphological characteristics and peptidoglycan synthesis of Escherichia coli cells. Microbios., 1987; 50: 43-59.

30. Turi M., Turi E., Koljalg S., Mikelsaar M. Influence of aqueous extracts of medicinal plants on surface hydrophobicity of Escherichia coli strains of different origin. APMIS, 1997; 105: 956-962. https://doi. org/10.1111/j.1699-0463.1997.tb05107.x

31. Cox S.D., Mann C.M., Markham J.L., Bell H.C., Gustafson 
J.E., Warmington J.R. et al., The mode of antimicrobial action of the essential oil of Melaleuca alternifolia (tea tree oil). J. Appl. Microbiol., 2000; 88: 170-175. https:// doi.org/10.1046/j.1365-2672.2000.00943.x

32. Ultee A., Bennik M.H., Moezelaar R. The phenolic hydroxyl group of carvacrol is essential for action against the food-borne pathogen Bacillus cereus. Appl. Environ. Microbiol., 2002; 68: 1561-1568. https://doi. org/10.1128/AEM.68.4.1561-1568.2002

33. Cristani M., Arrigo D.M., Mandalari G., Castelli F., Sarpietro M.G., Micieli D. et al., Interaction of Four Monoterpenes Contained in Essential Oils with Model Membranes: Implications for their Antibacterial Activity. J. Agric. Food Chem., 2007; 55: 6300-6308. https://doi.org/10.1021/jf070094x

34. Vardapetyan H., Tiratsuyan S., Hovhannisyan A., Rukhkyan M., Hovhannisyan D. Phytochemical composition and biological activity of Laurus nobilis $\mathrm{L}$. leaves collected from two regions of South Caucasus. J. Exp. Biol. Agri. Sci., 2013; 1: 45-51.

35. Consuelo D.M.M., Soledad P.C.M., Dolores C.M. Effect of drying method on the volatiles in bay leaf (Laurus nobilis L). J. Agric. Food. Chem., 2002; 50: 4520-4524. https://doi.org/10.1021/jf011573d

36. Pacificoa S., Gallicchio M., Lorenz P., Potenza N., Galasso S., Marciano S et al., Apolar Laurus nobilis Leaf Extracts Induce Cytotoxicity and Apoptosis Towards Three Nervous System Cell Lines. Food. Chem. Toxicol., 2013; 62: 628-637. https://doi.org/10.1016/j. fct.2013.09.029

37. Verdian-R.M., Hadjiakhoondi A. Essential oil composition of Laurus nobilis L. of different growth stages growing in Iran. Z.Naturforsch. C., 2008; 63: 785-788. https://doi.org/10.1515/znc-2008-11-1201

38. Ouchikh O., Chahed T., Ksouri R., Taarit M.B., Faleh H., Abdelly C., Kchouk E.M. et al., The Effects of Extraction Method on the Measured Tocopherol Level and Antioxidant Activity of $L$. nobilis Vegetative Organs. J. Food Comp. Anal., 2011; 24: 103-110. https://doi. org/10.1016/j.jfca.2010.04.006

39. Sampaio B.L., Edrada-Ebel R.A., Da Costa F.B. Effect of the environment on the secondary metabolic profile of Tithonia diversifolia: a model for environmental metabolomics of plants. Scientific Reports, 2016; 6: 29265. https://doi.org/10.1038/srep29265

40. Liu W., Yin D., Li N., Hou X., Wang D.,Li D. et al., Influence of Environmental Factors on Active Substance Production and Antioxidant Activity in Potentilla fruticosa L. and its Quality Assessment. Scientific Reports, 2016; 6: 28591. https://doi. org/10.1038/srep28591

41. Chen J., Jiang Q.D., Chai Y.P., Zhang H., Peng P., Yang, X.X. Natural terpenes as penetration enhancers for transdermal drug delivery. Molecules, 2016; 12: 1709. https://doi.org/10.3390/molecules21121709

42. Bhatti H.N.,Khan S.S., Khan A., Rani M., Ahmad V.U., Choudhary M.I. Biotransformation of monoterpenoids and their antimicrobial activities. Phytomedicine, 2014; 21: 1597-1626. https://doi.org/10.1016/j. phymed.2014.05.011

43. Guesmi F., Prasad S., Tyagi A.K., Landoulsi A. Antinflammatory and anticancer effects of terpenes from oily fractions of Teucruim alopecurus, blocker of $I \kappa B \alpha$ kinase, through downregulation of NF- $\kappa B$ activation, potentiation of apoptosis and suppression of NF-KB-regulated gene. Biomed. Pharmacother., 2017; 95: 1876-1885 https://doi.org/10.1016/j. biopha.2017.09.115

44. Koo H., Pearson S.K., Scott-Anne K., Abranches J., Cury J.A., Rosalen P.L., Park Y., Marquis R.E., Bowen W.H. Effects of apigenin and tt-farnesol on glucosyltransferase activity, biofilm viability and caries development in rats. Oral Microbiol. Immunol., 2002; 17: 337-343. https://doi.org/10.1034/j.1399302X.2002.170602.x

45. Zore G.B., Thakre A.D., Jadhav S., Karuppayil S.M. Terpenoids inhibit Candida albicans growth by affecting membrane integrity and arrest of cell cycle. Phytomedicine, 2011; 18: 1181-1190. https://doi. org/10.1016/j.phymed.2011.03.008

46. Yang Z., Wu N., Zu Y., Fu Y. Comparative anti-infectious bronchitis virus (IBV) activity of ( $\beta$ )-pinene: Effect on nucleocapsid (N) protein. Molecules, 2011; 16: 10441054. https://doi.org/10.3390/molecules16021044

47. Albuquerque M.R.J.R., Costa S.M.O., Bandeira P.N., Santiago G.M.P. Andrade-Neto M., Silveira E.R., Pessoa O.D.L. Nematicidal and larvicidal activities of the essential oils from aerial parts of Pectis oligocephala and Pectis apodocephala Baker. Ann. Braz. Acad. Sci., 2007; 79: 209-213. https://doi.org/10.1590/S000137652007000200003

48. de Paula S.B., Bartelli T.F., Di Raimo V., Santos J. P., Morey A.T., Bosini M.A., Nakamura C.V., Yamauchi L.M., Y. Ogatta S.F. Effect of Eugenol on Cell Surface Hydrophobicity, Adhesion, and Biofilm of Candida tropicalis and Candida dubliniensis Isolated from Oral Cavity of HIV-Infected Patients. Evid-Based. Compl. Alt. Med., 2014; Article ID 505204, 8 pages. https:// doi.org/10.1155/2014/505204

49. Kim Y.G., Lee J.H., Gwon G., Kim S., Park J.G., Lee J. Essential Oils and Eugenols Inhibit Biofilm Formation and the Virulence of Escherichia coli O157:H7. Sci. Rep., 2016; 6: 36377. https://doi.org/10.1038/srep36377

50. Ajayi O.E., Appel A.G., Fadamiro H.Y. Fumigation Toxicity of Essential Oil Monoterpenes to Callosobruchus maculatus (Coleoptera: Chrysomelidae: Bruchinae. J. Ins., 2014; Article ID 917212, 7 pages

51. Magalhaes C.B., Riva D.R., De Paula L., Brando-Lima A., Koatz V.L., Leal-Cardoso J.H., Zin W.A., Faffe D.S. In vivo anti-inflammatory action of eugenol on lipopolysaccharide-induced lung injury. J. Appl. Physiol., 2010; 108: 845-51. https://doi.org/10.1152/ japplphysiol.00560.2009

52. Manikandan P., Vinothini G., Priyadarsini V.R., Prathiba D., Nagini S. Eugenol inhibits cell proliferation via NF$\kappa B$ suppression in a rat model of gastric carcinogenesis induced by MNNG. Invest. New Drugs, 2011; 29: 110-117. https://doi.org/10.1007/s10637-009-9345-2

53. Panche A. N., Diwan A.D., Chandra S. R. Flavonoids: an overview. J. Nutri. Sci.,2016; 5 (e47): page 1 - 15. https://doi.org/10.1017/jns.2016.41

54. Gomes C.A., Cruz G.D.T., Andrade J.L., Milhazes N., Borges F., Marques M.P.M. Anticancer activity of phenolic acids of natural or synthetic origin: a 
structure-activity study. J. Med. Chem., 2003; 46: 5395-5401. https://doi.org/10.1021/jm030956v

55. Elvia Perez-Soto, Cynthia Carolina Estanislao-Gomez, David Guillermo Perez-Ishiwara, Crisalde Ramirez-Celis and Maria del Consuelo Gomez-Garcia. Cytotoxic Effect and Mechanisms from Some Plant-Derived Compounds in Breast Cancer. (August 6th 2019). https://www.intechopen.com/books/cytotoxicitydefinition-identification-and-cytotoxic-compounds/ cytotoxic-effect-and-mechanisms-from-some-plantderived-compounds-in-breast-cancer. https://doi. org/10.5772/intechopen.87177
56. Dias M.I., Barreira J. C.M., Calhelha R.C., Queiroz M.J.R. P.,Oliveira M. B. P. P.et al., Two-Dimensional PCA Highlights the Differentiated Antitumor and Antimicrobial Activity of Methanolic and Aqueous Extracts of Laurus nobilis L. from Different Origins. BioMed Res.Intl.,2014; Article ID 520464, 10 pages. https://doi.org/10.1155/2014/520464

57. Berrington D., Lall N. Anticancer activity of certain herbs and spices on the cervical epithelial carcinoma (HeLa) cell line. Evidence-Based Compl. Alt. Med., 2012; ID 564927:11 pages, https://doi. org/10.1155/2012/564927 